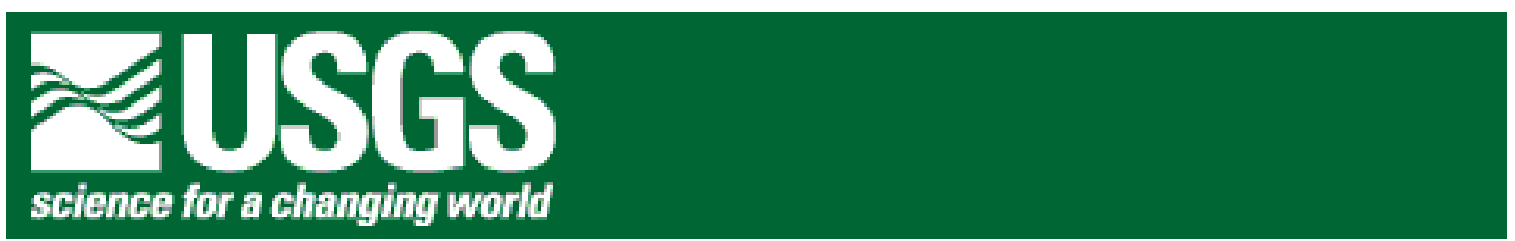

\title{
Assessment of mineral resource tracts in the Chugach National Forest, Alaska
}

By Steven W. Nelson ${ }^{1}$ and Marti L. Miller ${ }^{2}$

Open-File Report 00-026

This report is preliminary and has not been reviewed for conformity with the U.S.

Geological Survey editorial standards or with the North American Stratigraphic Code. Any use of trade, firm, or product names is for descriptive purposes only and does not imply endorsement by the U.S. Government.

UNITED STATES DEPARTMENT OF THE INTERIOR

U.S. GEOLOGICAL SURVEY

2000

2515 Cottonwood Street., Anchorage, AK 99508

2 U.S. Geological Survey, 4200 University Drive, Anchorage, AK 99508 


\title{
DISCLAIMER AND STATEMENT
}

This report was prepared under Cooperative Agreement No. 98WRAG1023 between the U.S. Geological Survey and the senior author. The purpose of the report is to provide mineral information useful to the Chugach National Forest (CNF) for preparation of the Chugach Land Use Management Plan (C-LUMP). The report focuses strictly on locatable mineral resources not on leasable resources, such as coal, oil, or gas.

The views and conclusions contained in this document are those of the authors and should not be interpreted as representing the opinions or policies of the U.S. Government. Mention of trade names or commercial products does not constitute their endorsement by the U.S. Government.

\begin{abstract}
Locatable minerals have been produced from the Chugach National Forest (CNF) for nearly 100 years. Past gold production has come from the Kenai Peninsula and the Girdwood, Port Wells, and Valdez areas. Copper and by-product gold and silver have been produced from mines at Ellamar, on Latouche Island, and near Valdez. Many of the past-producing properties were not mined out and contain significant inferred reserves of gold, copper, lead, zinc, and silver. This report outlines mineral resource areas (tracts) that contain both identified and undiscovered mineral resources. These tracts were drawn on the basis of one or more of the following criteria: (1) geochemical anomalies, (2) favorable geologic units, (3) presence of mines, prospects or mineral occurrences, and (4) geophysical anomalies. Bliss (1989) used six mineral deposit models to describe the types of deposits known from the CNF. Of these deposit types, only four are sufficiently known and defined in the CNF to be suitable for consideration in outlining and ranking of mineral resource tracts; these deposit types are: (1) Cyprus-type massive sulfide, (2) Chugach-type low-sulfide goldquartz veins, (3) placer gold, and (4) polymetallic vein.
\end{abstract}

The U.S. Bureau of Mines indicated that most of the inferred mineral reserves in the CNF would not be economic to produce under current prices. Small-scale placer gold operations are a possible exception. Other known resources that have recorded past production (oil, coal, rock, sand, and gravel) are not addressed in this report.

\section{INTRODUCTION}

This report builds on previous geologic and mineral studies. For more detailed background information, such as a geologic map and the location of mines, prospects, and mineral occurrences, the reader may refer to the following reports on the Chugach National Forest: Nelson and others (1984, 1985, 1994), Jansons and others (1984), and Bliss (1989). The mineral resource potential areas (tracts) that were defined and evaluated by Nelson and others (1984) are largely used in this report.

\section{LOCATION AND GEOGRAPHIC SETTING}

The Chugach National Forest, located in the Kenai-Chugach Mountains physiographic province of Alaska (Wahrhaftig, 1965), comprises parts of the Anchorage, Seward, Blying Sound, Valdez, Cordova, Middleton Island, Bering Glacier, and Icy Bay 1:250,000-scale quadrangles (fig. 1). The western boundary of the national forest is $72 \mathrm{~km}$ (45 mi) by road southwest of Anchorage, Alaska. 
The CNF, the second largest national forest in the United States, covers roughly $23,000 \mathrm{~km}^{2}$ $\left(9,000 \mathrm{mi}^{2}\right)$. This area includes Prince William Sound, the largest embayment along the coast of Alaska between Cook Inlet and Cape Spencer (near Glacier Bay). Prince William Sound includes numerous islands, the largest of which are Montague, Hinchinbrook, Knight, and Hawkins Islands (fig. 1).

There are numerous non-forest land in holdings within the boundaries of the Chugach National Forest including Native corporation lands, city and state lands, and patented mining claims. Under the provisions of the Alaska Native Claims Settlement Act of 1971, several Native villages/corporations selected about 400,000 acres of forest land for withdrawal as private land, and in 1984 these boundaries were being adjusted (Chugach National Forest Map, 1994). Continued adjustments of land ownership within the forest are the result of settlements following the Exxon Valdez oil spill claims. These settlements have resulted in some lands being returned to the national forest for management.

\section{MINING HISTORY}

The CNF lands have had a long history of mineral activity. In 1848, a Russian surveyor discovered gold in the Russian River area and placer gold was mined by the Russians near Kenai Lake in the early 1850's (Jansons and others, 1984). Strong interest in mineral development came after the United States purchased Alaska in 1867. By the late 1800's placer gold miners were active in the Kenai Peninsula area. Prospectors subsequently discovered lode gold deposits on the Kenai Peninsula, near Girdwood, in northern Prince William Sound, and near Valdez. The first notable production came in 1911 from mines in the Falls Creek area (Jansons and other, 1984). The most recent significant lode gold production from the Chugach National Forest was in the 1930's and 1940's. Little or no production from lode gold deposits has taken place since 1956.

Copper prospects have been developed or mined in the CNF since 1897. Systematic copper mining and ore shipments started from the Beatson mine $(\mathrm{S}-17)^{1}$ on Latouche Island in 1904, the Ellamar mine (C-91) near Valdez in 1905, and in 1912 from both the Schlosser mine (C-66) in Port Fidalgo and the Midas mine (V-35) near Valdez. Copper mining activity in Prince William Sound was closely tied to that of the Kennecott mines to the northeast in the Wrangle Mountains. The Kennecott mines closed in 1938 followed soon thereafter by the mines in the Prince William Sound area (Nelson and others, 1984).

Extensive coal occurrences in the Bering River area have been known since at least 1896 (Barnes, 1951). Rapid changes in thickness are common features of the coal seams, making them difficult to mine. Despite this structural complication, a minor amount of coal $(18,000$ to 20,000 tons) (Janson, 1979) was shipped between 1910 and 1920. There is currently no development interest in these coal deposits and in fact the local Native corporation is considering selling the land containing the coal back to the national forest (CNF staff, pers. commun., Jan. 1999).

Petroleum exploration began in the Katalla area in 1901 (Blasko, 1976), and in 1902, oil was struck at shallow depth. Between 1901 and 1930, 44 wells were drilled, 18 of which produced oil commercially at one time or another. Enough oil was pumped in the early 1900's to justify a local refinery. The refinery burned down in 1933 and was not rebuilt. Total oil production amounted to 153,922 barrels (Blasko, 1976).

\footnotetext{
${ }^{1}$ Letter-number combinations in parentheses refer to designation of mines, prospects, and occurrences complied in Jansons and others (1984) and shown on figure 2. Letters refer to, 1:250,000-scale quadrangles: C, Cordova; S, Seward; V, Valdez; or placer deposits, P.
} 


\section{ReVIEW of PAst Mineral ResourCe AsSESSMENTS}

This region of Alaska has had a long history of mineral assessment activity. Since the early part of the twentieth century numerous government studies were undertaken to describe the deposits and to determine their geologic association (Schrader, 1900; Johnson, 1914, 1915, 1918, 1919; Brooks, 1916; Martin, 1919; Bateman, 1924; Park, 1933; Tuck, 1933; Moffit and Fellows, 1950; Moffit, 1954). Beginning in the 1970's and continuing into the 1980's several quadrangles within the CNF area were evaluated under the Alaska Mineral Resource Assessment Program (AMRAP) of the U.S. Geological Survey (see table 1). Beginning in the 1980's more regional-scale mineral studies were completed under provisions of the Wilderness Act (Public Law 88-577, Sept. 1964) and involved joint investigations of the U.S. Geological Survey with the U.S. Bureau of Mines. A more recent study (Nelson and others, 1994), performed under an Interagency Agreement between the U.S. Forest Service, the U.S. Geological Survey, and the U.S. Bureau of Mines, evaluated a small, poorly known part of the CNF. The evaluations performed from 1970 on have focused on identifying tracts favorable for undiscovered mineral resources ${ }^{2}$ by the U.S. Geological Survey and tracts containing the known or identified mineral resources ${ }^{3}$ by the U.S. Bureau of Mines. These studies are summarized in table 1. Bliss (1989) reported the probabilistic estimates of undiscovered metal endowment within the CNF (table 2).

\section{METHODS}

\section{SUMMARY OF DEPOSIT TYPES}

Four deposit types are considered suitable for categorizing and ranking mineral resource tracts in the CNF. The four deposit types evaluated are as follows: (1) Cyprus-type massive sulfide deposits (referred to here as "Cyprus-type") containing $\mathrm{Cu}, \mathrm{Pb}, \mathrm{Zn}, \mathrm{Au}$, and Ag (Singer, 1986; Crowe and others, 1992); (2) Chugach-type low-sulfide gold-quartz veins (referred to here as "Chugach gold") containing both Au and Ag (Bliss, 1992; Goldfarb and others, 1986); (3) placer gold (Orris and Bliss, 1986); and (4) polymetallic veins containing $\mathrm{Cu}, \mathrm{Zn}, \mathrm{Pb}, \mathrm{Au}$, and $\mathrm{Ag}$ (Bliss, 1989; Nelson and others, 1994). Each of these deposit types is described in more detail below. Designation of mineral resource tracts was restricted to these types, because all metallic deposits that have shown historic development or production activity, or are presently producing, belong to one of these four types, and they constitute the major metallic resource potential for the CNF (Nelson and others, 1984; Bliss, 1989).

\section{Cyprus-type massive sulfide deposits}

Deposits of this type are found in a rock association of oceanic origin termed ophiolite (Coleman, 1977). The ophiolite assemblage is thought to represent a volcanic/plutonic section of oceanic crust formed along an axial graben in a mid-ocean or back-arc spreading ridge. From bottom to top, a typical ophiolite section has ultramafic rock, gabbro, sheeted dikes, pillow basalts, and a capping sedimentary rock sequence. A geothermal system involving the igneous rocks and circulating seawater produces submarine hot spring-type mineralization consisting of pyrite, chalcopyrite, sphalerite, and galena. The host rocks for the mineralization are usually the pillow basalts and sheeted dikes of the upper part of the ophiolite. In some systems stockworks of pyrite and pyrrhotite veins may extend for

\footnotetext{
2 Undiscovered resources-Undiscovered bodies of mineral-bearing material whose existence is surmised from broad (regional) knowledge and theory (Hansen, 1991, p. 95).

3 Identified resources-Resources whose location, grade, quality, and quantity are known or can be estimated from specific geologic evidence. Identified resources include economic, marginally economic, and subeconomic resources (Hansen, 1991, p. 95).
} 
hundreds of meters below the massive deposits (Crowe and others, 1992). Deposits of this type have been the major source of copper produced from the CNF. Gold is sometimes associated with the sulfide mineralization and streams adjacent to weathered massive sulfide deposits may contain gold placers.

Copper production in this region came from 23 mines and totaled approximately 94,653,000 $\mathrm{kg}(208,667,000 \mathrm{lbs})$ (Jansons and others, 1984). Copper has been the only base metal produced for sale. Four of the mines, Beatson (S-17), Ellamar (C-91), Midas (V-35), and Schlosser (C-66) accounted for nearly all of the production from the area. Zinc and minor amounts of lead are associated with the copper ore, but production of these was not recorded. By-product silver and gold were recovered at the smelter, usually amounting to less then $31 \mathrm{~g} / \mathrm{ton}(<1 \mathrm{oz} /$ tonne $)$ combined $\mathrm{Au}$ and $\mathrm{Ag}$.

\section{Chugach-type low-sulfide gold-quartz veins}

Quartz vein deposits in the CNF have characteristics that are consistent with the descriptive model for low-sulfide Au-quartz veins of Berger (1986). However, the typical Chugach gold deposit has about half the tonnage and half the grade value of the deposits defined by that model (Bliss, 1992). The Chugach gold deposits are normally found along faults and joints and show no "consistent association with igneous activity" (Goldfarb and others, 1986). Fluid inclusion data for the vein lodes in the CNF area suggest that deposition was by low-salinity fluids generated by low-grade metamorphism. The host rocks for these deposits are usually Valdez Group sedimentary rocks and to a lesser extent Orca Group sedimentary rocks (Nelson and others, 1984). Ideal conditions were met where the rocks were metamorphosed to medium greenschist facies (Goldfarb and others, 1986). The heat for metamorphism in the CNF is thought to be the result of the progressive subduction of the Kula-Farallon ridge in a fore-arc trench (Bradley and others, 1993). Another distinctive characteristic of the Chugach gold deposits is that they lack extensive wall-rock alteration typical of low-sulfide Au-quartz veins elsewhere (Berger, 1986).

Lode gold production is attributed to some 19 mines. The amount of past production ranges from $1,609 \mathrm{~kg}(51,740 \mathrm{oz})$ at the Cliff Mine (V-48) to $0.50 \mathrm{~kg}$ (16 oz) at McKinley Lake (C-6). Total lode gold production for the 19 mines was 3,665 kg $(117,854 \mathrm{oz})$ (Jansons and others, 1984).

\section{Placer gold deposits}

Gold placers develop downstream from a variety of gold-bearing lode deposits (Yeend, 1986). Placer deposits can also occur in areas lacking significant lodes. World wide, 17 major placer districts lie within lode-poor areas that are underlain by slate, phyllite, and schist (Wojcik, 1984). These source rocks are believed to be metamorphosed Au-rich shales, which, prior to metamorphism contained submicroscopic gold-bearing pyrite and other sulfides. Normally surface processes cannot effectively concentrate submicroscopic gold, thus Boyle (1979), suggested this gold would either be dispersed or dissolved during erosion. However, when the sulfide-bearing shale is metamorphosed, the contained gold increases in grain size so that concentration becomes possible during weathering and erosion.

Total placer gold production for the CNF is 4,140 kg (133,000 oz) gold. Most of this production has come from the Kenai Peninsula area; minor production has been recorded from other areas (Jansons and others, 1984).

Polymetallic vein deposits 
Polymetallic veins are a common deposit type found in several geologic associations. Cox (1986) suggested that this deposit type is related to shallow intrusive rocks in sedimentary and metamorphic terranes. Typical metals produced from the ores include $\mathrm{Ag}, \mathrm{Pb}$, and lesser $\mathrm{Au}, \mathrm{Cu}$, and $\mathrm{Zn}$ (Bliss and Cox, 1986). Deposits are thought to form near the paleo surface in fractures and breccias within the thermal aureole of clusters of intrusions. Deposits of this type are known to occur only in the Wells Bay-Long Bay tract (WB-LB, fig. 2) of the CNF. Several prospects were developed, but no production has been recorded (Roe, 1994). Goldfarb and others (1994) suggested that meteoric water circulation, driven by pluton emplacement, was important in the mineralizing process. It is unclear why this mineral deposit type is restricted to this tract, especially given the fact that intrusive bodies are found throughout the CNF. Possible explanations might be (1) the development of favorable conduits and structures in this area (Haeussler and Nelson, 1993), and (or) (2) a local relative shallow depth of emplacement of plutons that enhanced interaction with meteoric water.

\section{Unevaluated resources}

Other potential metallic resources have been identified in the CNF; these include $\mathrm{Ni}, \mathrm{Co}, \mathrm{S}$, Mo, Fl, Ga, Mn, U, Sn, Sb, and W (Nelson and others, 1984; Hoekzema, 1984; Goodfellow and others, 1984; Kurtak, 1982). These were not considered in defining mineral tracts for any of several reasons: they have had no history of production; they lack diagnostic geologic criteria needed for classification using Cox and Singer (1986) models; or, if they do fit the criteria for a deposit type, their tonnage and grade is so low as to be considered insignificant. It is important to realize that future, more detailed study of these possible resources could change this interpretation.

\section{DEFINITION OF TRACTS}

The mineral-resource tracts used in this report (fig. 2) are based on tracts originally defined by Nelson and others (1984) that were slightly modified by staff from the U.S. Geological Survey, the Chugach National Forest, and others during a series of meetings in February 1999 (table 3). The following types of modifications were made: (1) the boundaries of some areas were modified using detailed information about active placer operations (information provided by the CNF); (2) three new tracts were added representing areas not previously evaluated; (3) the ranking of some tracts was upgraded based on post-1984 work; and (4) some tracts were divided into those containing identified (known) resources and those containing undiscovered resources.

The tracts were classified into several categories of mineral potential based on the presence of one or more of the following criteria ${ }^{4}$ : (1) permissive geology for a specific type of mineral deposit (using Nelson and others, 1985); (2) known mines (including placer operations), prospects, or occurrences of one of the four deposit types defined above (using Jansons and others, 1984); (3) significant geochemical anomalies appropriate to the deposit type in either rock, heavy-mineral-concentrate, or stream-sediment samples (using Goldfarb and others, 1984); and (4) geophysical anomalies supportive of the permissive geology (using Barnes and Morin, 1990; Barnes, 1991). This evaluation allowed the tracts to be classified into one of four categories: (1) tracts containing identified mineral resources (mines and prospects) and considered highly favorable for future mineral development and production, (2) tracts containing identified mineral resources and considered moderately favorable for future mineral development and production, (3) tracts without identified resources, but considered highly favorable for containing undiscovered mineral resources, and (4) tracts considered under-evaluated as to their mineral resource potential, because

\footnotetext{
${ }^{4}$ Nelson and others (1984, table 7) used the same criteria.
} 
geologic data is lacking due to rugged topography and (or) glacial cover. Areas not included within a mineral tract were excluded for the following reasons: they lack geologic criteria indicative of the four deposit types, they are considered to have a low possibility of future mineral development activity (Nelson and others, 1984, table 7), or they contain resources not addressed in this report.

\section{TRACT DESCRIPTIONS}

The mineral-resource tracts defined for this report are identified by geographic name and described below. In the Nelson and others (1984) report, mineral tracts were identified by a number; the old numbers and new geographic names are shown in table 3 for ease of comparison. The table also indicates which of the original numbered tracts were modified for this report.

$\operatorname{GiRDWOOD}$ (G, fig. 2)

This tract is outlined on the basis of both placer and lode gold potential. It contains several mines and prospects, but only the placer operations are currently active. Three areas of this tract contain identified resources of gold and are considered highly favorable for future mineral development and production from both placer and Chugach-gold deposits. The remainder of the tract is considered highly favorable for containing undiscovered gold resources based on geologic and geochemical data.

RESURRECTION CREEK (RC, fig. 2)

This tract is defined by the presence of identified gold from both placer and Chugach-gold deposits, as well as from Cyprus-type copper deposits. Seven areas within the tract are considered highly favorable for mineral development and production; the remainder of the tract is considered moderately favorable for mineral development and production. In addition to containing many past-producing mines and prospects, geologic data support some potential for the presence of undiscovered resources of the above three deposit types (Nelson and others, 1984, table 7; Bliss, 1989). Swainbank and others (1997) reported some gold exploration activity at the following locations within this tract: Canyon Creek (P76, 77), Quartz Creek (P-81), Bear Creek (P-91), and the Gilpatrick mine (S-253).

KenAi LAKE (KL, fig. 2)

This tract is defined by the presence of identified resources of gold from both placer and Chugach-gold deposits. Five areas within the tract are considered highly favorable for mineral development and production; the remainder of the tract is considered moderately favorable for mineral development and production. This tract contains many past-producing mines and prospects, however, only placer operations are currently active. Geologic data support some potential for undiscovered resources of both placer and lode gold in this tract (Nelson and others, 1984, table 7; Bliss, 1989).

RESURRECTION PENINSUla (RP, fig. 2)

This tract contains identified resources and is considered moderately favorable for future mineral development and production of $\mathrm{Cu}, \mathrm{Pb}, \mathrm{Zn}, \mathrm{Au}$, and $\mathrm{Ag}$ from Cyprus-type deposits. In addition to containing previously active prospects and exhibiting geochemical anomalies, the presence of mineralization in favorable rock types suggests the tract has the potential for undiscovered resources from Cyprus-type deposits.

HARRIMAN FJORD (HF, fig. 2) 
This tract is defined by the presence of identified resources of gold from both placer and Chugach gold deposits. Two areas in the tract are considered highly favorable for future mineral development and production; the remainder of the tract is considered moderately favorable for mineral development and production. This tract contains past-producing mines and prospects, including the second largest gold-producing operation in the CNF at the Granite mine (S-147). Geologic data support potential for the discovery of additional resources in the above two deposit types (Nelson and others, 1984, table 7; Bliss, 1989).

Blackstone Glacier (BG, fig. 2)

This tract is outlined for both placer and lode-gold potential. One area within the tract contains identified resources of gold from placers along the Kings River (P-46) and is considered highly favorable for future mineral development and production. The bulk of this tract is considered highly favorable for containing undiscovered resources of gold from placer and Chugach-gold deposits based on the presence of favorable host rocks, observed mineral occurrences, and supportive geochemical data (Nelson and others, 1984, table 7).

\section{SARGENT ICEFIELD (SI, fig. 2)}

This tract, which was not evaluated by Nelson and others (1984), is considered underevaluated due to rugged topography and glacial cover. Both to the north and south, tracts are ranked favorable for containing undiscovered gold resources and it is possible that if geologic data were acquired, this area would also rank as favorable for undiscovered gold.

Puget Bay (PB, fig. 2)

This tract is considered to be highly favorable for the presence of undiscovered gold resources from Chugach gold and placer deposits. This conclusion is based on the following: host rocks of favorable metamorphic grade are present (Goldfarb and other, 1986), a few mineral occurrences of this type are known, and geochemical data is supportive. New studies on the favorable association of mid-greenschist facies metamorphism with gold deposits (Goldfarb and others, 1986) has led to a higher favorability ranking of this tract than reported for the same area in Nelson and others (1984, table 7).

\section{College Fuord-Columbia Glacier (CF-CG, fig. 2)}

This tract is considered under-evaluated due to rugged topography and glacial cover. Both to the south and southwest, tracts that contain identified gold resources are considered highly favorable for also containing undiscovered gold resources from Chugach gold and possibly placer deposits. Geologic continuity between this tract and the two that containing identified gold resources, suggests that if geologic data were acquired, this tract would likely also rank as highly favorable.

\section{Port Wells-Columbia Glacier (PW-CG, fig. 2)}

This tract is outlined for both placer and Chugach gold deposits. Two areas within the tract contain identified gold resources from past-producing mines and prospects: (1) an area on the southwestern end of the tract is considered moderately favorable for mineral development); and (2) an area on the east end of the tract is considered highly favorable for future mineral development and production of gold from placers and Chugach gold deposits. The eastern end of the tract is part of a mineralized belt that trends outside of the CNF eastward to the Valdez area (Winker and others, 1981) and beyond where it may re- 
enter the CNF in the Copper River Addition tract (described below). The remainder of the tract is considered highly favorable for the presence of undiscovered gold resources based on supportive geology and geochemistry.

\section{CULROSS ISLAND (CI, fig. 2)}

This tract has identified gold resources of the Chugach gold type (Jansons and others, 1984) and is classified as moderately favorable for future mineral development and production. This tract contains the Culross mine (S-102) and one prospect.

KNIGHT ISLAND (KI, fig. 2)

This tract contains identified resources of $\mathrm{Cu}, \mathrm{Pb}, \mathrm{Zn}, \mathrm{Au}$, and $\mathrm{Ag}$ from Cyprus-type deposits. One area within the tract is considered highly favorable for future mineral development and production; the remainder of the tract is considered moderately favorable. In addition to containing many prospects, this tract has seen recent exploration interest by industry. The continuity of geochemical anomalies, geophysical anomalies (Barnes and Morin, 1990; Barnes, 1991), and observed mineralization in favorable rock types suggests that the Knight Island, Latouche Island, Glacier Island, and Ellamar-Port Fidalgo tracts are part of a mineralized belt that has potential for containing undiscovered Cyprus-type deposits (Nelson and others, 1984; Crowe and others, 1992). The Rua Cove prospect (S67) contains an estimated 1.3 million $\mathrm{mt}$ of ore reserves at an average grade of 1.2 percent $\mathrm{Cu}$ (Jansons and others, 1984).

\section{LATOUCHE ISLAND (LI, fig. 2)}

This tract contains identified resources of $\mathrm{Cu}, \mathrm{Pb}, \mathrm{Zn}, \mathrm{Au}$, and $\mathrm{Ag}$ from Cyprus-type deposits. One area within the tract is considered highly favorable for future mineral development and production; the remainder of the tract is considered moderately favorable. This tract contains previously active mines and prospects. The Beatson mine (S-17) had the greatest production of copper in the $\mathrm{CNF}$, amounting to 83 million $\mathrm{kg} \mathrm{Cu}$ (182.6 million pounds). This value is 87 percent of the total copper produced from the entire CNF (Jansons and others, 1984). For undiscovered mineral potential see Knight Island, above.

\section{Wells BAY-Long BAY (WB-LB, fig. 2)}

This tract contains identified resources of $\mathrm{Ag}, \mathrm{Cu}, \mathrm{Pb}$, and $\mathrm{Zn}$ from polymetallic vein deposits (Bliss, 1989; Nelson and others, 1994; Roe, 1994). The central part of the tract is considered highly favorable for future mineral development and production; the remainder of the tract is considered moderately favorable. Polymetallic veins like these are not recognized elsewhere in geologically similar regions of southern Alaska (Nelson and others, 1994). There has been no production from this tract, but estimates from ten prospects suggest a total reserve base of about 200,000 mt ore (Roe, 1994). This tract also has potential for containing undiscovered resources from polymetallic vein deposits (table 2).

GLACIER ISLAND (GI, fig. 2)

This tract contains identified resources (from previously active prospects) of $\mathrm{Cu}, \mathrm{Pb}, \mathrm{Zn}, \mathrm{Au}$, and Ag from Cyprus-type massive sulfide deposits and is considered moderately favorable for future mineral development and production. For undiscovered mineral potential see Knight Island, above.

Ellamar-Port FidALGO (E-PF, fig. 2) 
This tract contains identified resources of $\mathrm{Cu}, \mathrm{Pb}, \mathrm{Zn}, \mathrm{Au}$, and $\mathrm{Ag}$ from Cyprus-type deposits. Three areas within the tract are considered highly favorable for mineral development and production. Previously active mines and prospects are contained within the highly favorable areas. The Ellamar mine (C-91) had the second greatest production of copper in the $\mathrm{CNF}$, yielding 7.1 million $\mathrm{kg} \mathrm{Cu}$ (15.7 million pounds). The Schlosser mine (C-66) had the third highest amount of Cu production, yielding 1.9 million $\mathrm{kg}$ (4.16 million pounds). In addition to its identified resources, this tract is considered highly favorable for containing undiscovered resources from Cyprus-type deposits (see Knight Island, above). Geochemical anomalies and favorable rock types also suggest the tract has some potential for containing undiscovered gold resources from Chugach-gold deposits in the eastern lobe of this tract (Goldfarb and others, 1992).

\section{COPPER River AdDITION (CRA, fig. 2)}

This is the largest tract in the CNF that is considered highly favorable for containing undiscovered mineral resources. Mineralized belts outside of the CNF that contain mines and prospects defined by the Cyprus-type, Chugach gold, and placer gold deposit models, trend east into this tract (Nelson and others, 1984). Based on the presence of favorable geologic units, known mineral occurrences, geochemical anomalies, and geophysical data (Nelson and others, 1984, table 7) these mineralized belts likely continue into this tract, making it highly favorable for containing undiscovered resources. In most of this tract minerals are managed under ANILCA requirements (leasable) not under the 1872 Mining Law (locatable).

\section{HINCHINBROOK ISLAND-HAWKINS ISLAND-CORDOVA (HI-HI-C, fig. 2)}

This tract is comprised of three areas, the eastern most of which contains identified resources of $\mathrm{Cu}, \mathrm{Pb}, \mathrm{Zn}, \mathrm{Au}$, and $\mathrm{Ag}$ from Cyprus-type deposits and is considered moderately favorable for mineral development and production. About 30 prospects and occurrences are known in this area (Jansons and others, 1984). The Hawkins Island and Hinchinbrook Island areas of this tract are considered highly favorable for containing undiscovered resources from Cyprus-type deposits.

\section{MCKINLEY PEAK (MP, fig. 2)}

This tract contains identified gold resources and has a moderately high potential for development and production of Chugach-gold deposits. The McKinley Lake mine (C-6), and several prospects are contained within this tract (Haney and Jansons, 1987); however, production from this mine was minor at only $0.5 \mathrm{~kg}(16 \mathrm{oz})$ of gold.

\section{Miles Glacier (MG, fig. 2)}

This tract, which was not evaluated by Nelson and others (1984), is considered underevaluated due to rugged topography and glacial cover. Geologic units from the Copper River Addition tract (discussed above), trend east into this tract, however, rocks underlying the Miles Glacier tract show evidence of higher-grade metamorphism (Miller and others, 1984) than those to the west. This grade is probably too high for Chugach-gold mineralization to have formed (Goldfarb and others, 1986). Deposit types other than those considered in this report may exist in this area, but the lack of geologic data makes classification of this tract difficult.

Mt. Hamilton (MH), Don Miller Hills (DMH), AND KAYAK IsLAND (KA) (all shown in fig. 2) 
These three tracts are considered together because of their similar geology. These tracts were part of larger tracts evaluated by Nelson and others (1984) that contain identified resources of coal, oil, and gas (Barnes, 1951; Plafker, 1987), but these resources are not considered in this report. All three tracts are considered highly favorable for containing undiscovered mineral resources from an as yet, unidentified deposit type. Anomalous metal values in drainage-basin samples indicate that some of the sedimentary rock units are possible hosts for zinc-rich sulfide deposits (Pickthorn and others, 1985; Goldfarb and others, 1992). Heavy-mineral-concentrate samples from these tracts contain abundant sphalerite and barite. Some concentrates contained greater than 50,000 ppm zinc, and locally cadmium and molybdenum values were elevated. More significantly, streamsediment samples contained up to 9,000 ppm barium. These tracts represent one of three areas previously identified by Nelson and others (1994) as needing additional mineral study.

\section{CURRENT EXPLORATION AND DEVELOPMENT POTENTIAL}

Active mineral exploration in the CNF began in the late 1800's, but most of that activity ceased by the 1930's. Since then, exploration has only been sporadic and strongly tied to the price of metals. At present, some private and national forest lands are being evaluated by industry in the hope of discovering new Cyprus-type deposits in the Latouche Island, Knight Island, and Ellamar-Port Fidalgo tracts.

Placer gold operations, which represent the only current production activity, have declined in number in the last 10 years. From 1979 to 1982, small placer operations in the Girdwood, Resurrection Creek, and Kenai Lake tracts, together produced an estimated $211 \mathrm{~kg}(6,800$ oz) of gold (Hoekzema and Fechner, 1986). Gold production information since 1982 is not readily available, but values from the entire south-central Alaska region (which includes the $\mathrm{CNF}$ ) suggest a decline. Placer gold production for all of south-central Alaska was reported as $30.1 \mathrm{~kg}$ (971 oz) for 1997 (Swainbank and others, 1997). Clearly production for the CNF has significantly declined since the 1979-1982 period.

Three parameters are needed to fully assess the mineral resource development potential of the CNF. The first is the undiscovered mineral endowment discussed in Bliss (1989) and shown in table 2. The second is the estimate of mineral reserve base for the identified resources; this is reported as the inferred mineral endowment (discussed below) by Jansons and others (1984), Sherman (1987), Hoekzema and Fechner (1986), and Roe (1994). The third parameter is the feasibility of developing these resources under current metal values.

The CNF contains a significant inferred mineral reserves, which lie mostly in areas of pastmining activity. Jansons and others (1984) reported the following reserve estimates: an inferred placer reserve base of at least $8,980,000 \mathrm{~m}^{3}\left(11,750,000 \mathrm{yd}^{3}\right)$ of gold-bearing gravels, an inferred gold reserve base (for mines containing $>200 \mathrm{mt}$ ore) of about 108,000 mt ore containing up to $6,200 \mathrm{~kg}(200,000 \mathrm{oz})$ gold from Chugach-gold deposits (Sherman, 1987), and a copper reserve base of $>7,000,000 \mathrm{mt}$ ore (at an average grade of 2.0 percent $\mathrm{Cu})$ or $127,000,000 \mathrm{~kg}(280,000,000 \mathrm{lbs})$ copper from Cyprus-type deposits. An additional $230,000 \mathrm{mt}$ of $\mathrm{Cu}-\mathrm{Pb}-\mathrm{Zn}-\mathrm{Ag}$ ore of variable grades from ten polymetallic vein prospects are estimated for the Wells Bay-Long Bay tract (Roe, 1994).

Bulk placer sampling from drainages in the CNF indicate that anomalous placer gold occurs in most drainages underlain by the Valdez Group sedimentary rocks and the highest concentrations occur in streams that have had a history of placer gold production (Hoekzema and Fechner, 1986). If we assume that future production will also come from these same drainages, then the bulk of placer gold reserve base would be found in the Girdwood, Resurrection Creek, and Kenai Lake tracts. No grades are given for this inferred 
reserve base, and placer areas that show past production are of variable grade (Jansons and others, 1984). The feasibility of mining this gold is dependent on the value of gold. Sherman and Jansons (1984) suggested that for large-scale placer operations to be economically viable, gold would have to be $\$ 13.00 / \mathrm{g}(\$ 400 / \mathrm{oz})$ and the amount of gravel processed would have to be a minimum of $380 \mathrm{~m}^{3} /$ day $\left(500 \mathrm{yd}^{3} /\right.$ day $)$. It is not surprising then that only small-scale, seasonal placer operations are currently active.

Of the above inferred reserve estimate of $6,200 \mathrm{~kg}$ gold from Chugach-gold deposits, about half is from the Resurrection Creek tract. For a break-even operation, the feasibility of mining this lode gold depends on a gold value of $\$ 14.70 / \mathrm{g}(\$ 456 / \mathrm{oz})$ and a minimum reserve base of 100,000 mt @ $15.5 \mathrm{~g} /$ tonne $(0.5 \mathrm{oz} /$ ton $)$ gold over a $1.2 \mathrm{~m}(4 \mathrm{ft})$ mining width (Sherman and Jansons, 1984). None of the known mines contain this amount of reserve base; in fact the total inferred reserve tonnage for the 32 mines is about this same amount (Jansons and others, 1984). Without a significant tonnage and high grade, this deposit type is unlikely to see any large-scale activity.

The copper reserve estimate from 23 mines and prospects is estimated to be 127,000,000 $\mathrm{kg}$. Most of this amount would be from the Latouche Island, Knight Island, Glacier Island, and Ellamar-Port Fidalgo tracts. Sherman and Jansons (1984) estimated the parameters for economically borderline open-pit and underground mining operations. For an open-pit operation, production would have to be $11,000 \mathrm{mt} /$ day at the following metal values: $\$ 1.54 \mathrm{~kg}(\$ 0.70 / \mathrm{lbs})$ copper, $\$ 0.82 \mathrm{~kg}(\$ 0.37 / \mathrm{lbs})$ zinc, $\$ 12.90 / \mathrm{g}(\$ 400 / \mathrm{oz})$ gold, and $\$ 0.32 / \mathrm{g}(\$ 10 / \mathrm{oz})$ silver. For an underground operation, metal production would have to be $1,650 \mathrm{mt} /$ day at the following metal values: $\$ 1.65 \mathrm{~kg}(\$ 0.75 / \mathrm{lbs})$ copper, $\$ 4.32 \mathrm{~kg}$ (\$1.96/lbs) zinc, and gold and silver as above.

Copper, lead, zinc, and silver from ten prospects of polymetallic veins in the Wells BayLong Bay tract were estimated to contain inferred reserves of 230,000 mt of ore. Roe (1994) concluded that none of these prospects has sufficient tonnage or grade to make current production possible.

\section{CONCLUSIONS}

Twenty-three resource tracts are outlined in this report. Four deposit types have a past history of development or production of $\mathrm{Au}, \mathrm{Ag}, \mathrm{Cu}, \mathrm{Pb}$, and (or) $\mathrm{Zn}$. Thirteen of these tracts (G, RC, KL, RP, HF, BG, PW-CG, WB-LB, GI, KI, LI, E-PF, C-HI-HI, fig. 2) contain identified resources that may sustain future development and production, and may contain undiscovered resources. Two tracts (CI and MP) contain identified gold resources. Two other tracts (PB and CRA) are favorable for containing undiscovered resources of three deposit types. Three tracts (MH, DMH, and KA) contain highly anomalous geochemical values for $\mathrm{Zn}$ and $\mathrm{Ba}$ and warrant more detailed exploration and evaluation to confidently assess this mineral potential. Three other tracts (SI, CF-CG, and MG) are considered under-evaluated due to rugged topography and glacial cover. Given more geologic data, these tracts could be better evaluated as to their resource potential.

The most likely tracts to see future mineral development and production (under favorable economic conditions) for placer gold and Chugach gold are G, RC, KL, HF, PW-CG, and BG. The most likely tracts to see future activity for Cyprus-type deposits $(\mathrm{Cu}, \mathrm{Pb}, \mathrm{Zn}, \mathrm{Au}$, $\mathrm{Ag}$ ) are LI, KI, and E-PF. The largest tract, CRA represents an extension of known mineral belts outside of the CNF and is considered highly favorable for containing undiscovered resources from deposits of Chugach gold and placer gold, as well as Cyprus-type deposits.

Any production from either the inferred reserves or from as yet undiscovered deposits will be strongly dependent on metal values. Current feasibility evaluations suggest that 
production is unlikely for any of the lode deposits at current metal prices. Placer gold production, on a small scale, is likely to continue in the more easily accessible areas that have had a previous history of placer activity.

\section{AKNOWLEDGEMENTS}

We thank Dave Brew (U.S.G.S., emeritus) and D.A. Singer (U.S.G.S.) for their informal reviews of earlier drafts of this report and for guidance through the intricacies of various assessment methodologies. Judy Weathers and Nora Shew (of the U.S.G.S.) and Karin Preston, Paula Smith, and Linda Kelley (of the U.S.F.S) provided excellent drafting support.

\section{REFERENCES CITED}

Barnes, D.F., 1991, Map showing interpretation of aeromagnetic data for the Chugach National Forest, Alaska: U.S. Geological Survey Miscellaneous Field Studies Map, MF 1645-H, scale 1:250,000.

Barnes, D.F., and Morin, R.L., 1990, Gravity contour map and interpretation of gravity data for the Chugach National Forest, Alaska: U.S. Geological Survey Miscellaneous Field Studies Map, MF 1645-F, scale 1:250,000.

Barnes, F.F., 1951, Review of the geology and coal resources of the Bering River coal field, Alaska: U.S. Geological Survey Circular 146, 11 p.

Bateman, A.M., 1924, Geology of the Beatson copper mine, Alaska: Economic Geology, v. 19 , no. 4 , p. 339-368.

Berger, B.R., 1986, Descriptive model of low-sulfide Au-quartz veins, in, Cox, D.P., and Singer, D.A., eds., Mineral Deposit Models: U.S. Geological Survey Bulletin 1693, p. 239.

Blasko, D.P., 1976, Oil and gas seeps in Alaska, north-central Gulf of Alaska: U.S. Bureau of Mines RI 8136, $123 \mathrm{p}$.

Bliss, J.D., 1989, Quantitative mineral resource assessment of undiscovered mineral deposits for selected mineral deposit types in the Chugach National Forest, Alaska: U.S. Geological Survey Open-file Report, OF 89-345, 22 p. 1992, Grade and tonnage model of Chugach-type low-sulfide Au-quartz veins, in, Bliss, J.D., ed., Development in Mineral Deposit Modeling: U.S. Geological Survey Bulletin 2004, p.44-46.

Bliss, J.D., and Cox, D.P., 1986, Grade and tonnage model of polymetallic veins, in, Cox, D.P., and Singer, D.A., eds., Mineral Deposit Models: U.S. Geological Survey Bulletin 1693, p. 125-129.

Boyle, R.W., 1979, The geochemistry of gold and its deposits: Geological Survey of Canada Bulletin 280, 584 p.

Bradley, D.C., Haeussler, P.J., and Kusky, T.M., 1994, Timing of early Tertiary ridge subduction in southern Alaska, in, Dusel-Bacon, Cynthia, and Till, A.B., eds., Geologic Studies in Alaska by the U.S. Geological Survey, 1992: U.S. Geological Survey Bulletin 2068, p. 163-177.

Brooks, A.H., 1916, The Alaska mining industry in 1915: U.S. Geological Survey Bulletin 642, p. 16-71.

Chugach National Forest Map, 1994, U.S. Department of Agriculture, R10-RG-77.

Coleman, R.G., 1977, Ophiolite-Ancient Oceanic Lithosphere?: Springer-Verlag, New York, $229 \mathrm{p}$.

Cox, D.P., 1986, Descriptive model of polymetallic veins, in, Cox, D.P., and Singer, D.A., eds., Mineral Deposit Models: U.S. Geological Survey Bulletin 1693, p.125.

Cox, D.P., and Singer, D.A., eds., 1986, Mineral Deposit Models: U.S. Geological Survey Bulletin 1693, 379 p. 
Crowe, D.E., Nelson, S.W., Brown, P.E., Shanks, W.C., III, and Valley, J.W., 1992, Geology and geochemistry of volcanogenic massive sulfide deposits and related igneous rocks, Prince William Sound, south-central Alaska: Economic Geology, v. 87, p. $1722-1746$.

Goldfarb, R. J., Case, J.E., Plafker, George, and Winkler, G.R., 1992, Maps showing areas of potential for mineral resources in the Cordova and Middleton Island $1^{\circ} \times 3^{\circ}$ quadrangles, southern Alaska: U.S. Geological Survey Miscellaneous Field Studies Map, MF-2190, scale 1:250,000.

Goldfarb, R.J., Gent, C.A., Gray, J.E., and Nelson, S.W., 1994, Isotopic constraints on the genesis of base-metal-bearing mineral occurrences near Columbia Glacier, northern Prince William Sound, Alaska, in, Till, A.B., and Moore, T.E., eds., Geologic Studies in Alaska by the U.S. Geological Survey 1992: U.S. Geological Survey Bulletin 2107, p. 73-82.

Goldfarb, R.J., Leach, D.L., Miller, M.L., and Pickthorn, W.J., 1986, Geology, metamorphic setting, and genetic constraints of epigenetic lode-gold mineralization within the Cretaceous Valdez Group, south-central Alaska, in, Keppie, J.D., Boyle, R.W., and Haynes, S.J., eds., Turbidite-hosted Gold Deposits: Geological Association of Canada Special Paper 32, p. 87-105.

Goldfarb, R. J., Nelson, S.W., Dumoulin, J.A., Miller, M.L., Day, G.W., Hoffman, J.D., Tripp, R. B., Smaglik, Suzanne, and Folger, Peter, 1984, Data report and statistical summary for samples of moraine and stream-sediment, nonmagnetic heavy-mineral concentrates, and rock samples from the Chugach National Forest, Alaska: U.S. Geological Survey Open-file Report 84-355.

Goodfellow, R., Nelson, S.W., Bouse, R.M., and Koski, R.A., 1984, The geologic setting and composition of a newly discovered manganese deposit on Hinchinbrook Island, Alaska: U.S. Geological Survey Open-file Report, OF 84-671, 50 p.

Haeussler, P.J., and Nelson, S.W., 1993, Structural evolution of the Chugach-Prince William terrane at the hinge of the orocline in Prince William Sound, and implications for ore deposits, in, Dusel-Bacon, Cynthia and Till, A.B., eds., Geologic Studies in Alaska by the U.S. Geological Survey, 1992: U.S. Geological Survey Bulletin 2068, p. 130-142.

Haney, J.M., and Jansons, Uldis, 1987, Geology of the McKinley Lake gold area, Chugach National Forest, south-central Alaska: U.S. Bureau of Mines Open-file Report OF 32-87, $40 \mathrm{p}$.

Hansens, W.R., 1991, Suggestions to Authors of the Reports of the United States Geological Survey, (7th ed.): Washington, D.C., U.S. Government Printing Office, $289 \mathrm{p}$.

Hoekzema, R.B., 1984, Strategic and critical mineral development potential of the Chugach National Forest, south-central Alaska: U.S. Bureau of Mines Open-file Report, OF 215-84, $64 \mathrm{p}$.

Hoekzema, R.B., and Fechner, S.A., 1986, Placer gold in and near the Chugach National Forest, Alaska: U.S. Bureau of Mines Information Circular, IC 9091, 42 p.

Janson, L.E., 1979, The Copper Spike: Anchorage, Alaska, Alaska Northwest Publishing Company, $175 \mathrm{p}$.

Jansons, Uldis, Hoekzema, R. B., Kurtak, J. M., and Fechner, S. A., 1984, Mineral occurrences in the Chugach National Forest, south-central Alaska: U.S. Bureau of Mines Open-file Report MLA 5-84, 36 p.

Johnson, B.L., 1914, The Port Wells gold-lode district: U.S. Geological Survey Bulletin 592, p.195-236. 1915, The gold and copper deposits of the Port Valdez district: U.S. Geological Survey Bulletin 622, p. 140-188. 1918, Copper deposits of the Latouche and Knight Island districts, Prince William Sound: U.S. Geological Survey Bulletin 622, p. 193-220. 
1919, Mining on Prince William Sound: U.S. Geological Survey Bulletin 692, p. 143-151.

Kurtak, J. M., 1982, A manganese occurrence on Chenega Island, Prince William Sound, Alaska: U.S. Bureau of Mines Open-file Report, MLA 124-82, 9 p.

MacKevett, E. M., Jr., and Holloway, C.D., 1977, Metalliferous and selected nonmetalliferous mineral deposits in western southern Alaska: U.S. Geological Survey Open-file Report, OF 77-169F, scale 1:1,000,000.

Madden-McGuire, Dawn, and Winkler, G.R., 1994, Mineral resource potential maps of the Anchorage $1^{\circ} \times 3^{\circ}$ quadrangle, Alaska: U.S. Geological Survey Map I-2393, scale $1: 250,000$.

Martin, G.C., 1919, The Alaskan mining industry in 1917: U.S. Geological Survey Bulletin 692, p. 11-42.

Miller, M.L., Dumoulin, J.A., and Nelson, S.W., 1984, A transect of metamorphic rocks along the Copper River, Cordova, and Valdez quadrangles, Alaska, in, Reed, K.W., and Bartsch-Winkler, Susan, eds., U.S. Geological Survey Accomplishments in Alaska, 1982: U.S. Geological Survey Circular 939, p. 52-57.

Moffit, F.H., 1954, Geology of the Prince William Sound region, Alaska: U.S. Geological Survey Bulletin 989-B, p. 225-310.

Moffit, F.H., and Fellows, R.E., 1950, Copper deposits of the Prince William Sound district, Alaska: U.S. Geological Survey Bulletin 963-B, p. 47-80.

Nelson, S. W., Dumoulin, J. A., and Miller, M. L., 1985, Geologic map of the Chugach National Forest, Alaska: U.S. Geological Survey Miscellaneous Field Studies Map MF-1645-B, 16 p., scale 1:250,000.

Nelson, S.W., Miller, M.L., Barnes, D.F., Dumoulin, J.A., Goldfarb, R.J., Koski, R.A., Mull, C.G., Pickthorn, W.J., Jansons, Uldis, Hoekzema, R.B., Kurtak, J.M., and Fechner, S.A., 1984, Mineral resource potential of the Chugach National Forest, Alaska: U. S. Geological Survey Miscellaneous Field Studies Map MF-1645-A, 24 p., scale $1: 250,000$.

Nelson, S.W., Miller, M.L., Goldfarb, R.J., Snee, L.W., Sherman, G.E., Roe, C.H., and Balen, M.D., 1994, Mineral resource assessment of the Chugach National Forest Special Study area in northern Prince William Sound, Alaska: U.S.Geological Survey Open-file Report OF 94-272.

Orris, G.J., and Bliss, J.D., 1986, Grade and tonnage model of placer Au-PGE, in, Cox, D.P., and Singer, D.A., eds., Mineral Deposit Models: U.S. Geological Survey Bulletin 1693, p. 261-264.

Park, C.F., Jr., 1933, The Girdwood district, Alaska: U.S. Geological Survey Bulletin 849G, p. 381-424.

Pickthorn, W.J., Goldfarb, R.J., O’Leary, R.M., Sutley, S.J., and Weaver, S.C., 1985, Kayak Island--Analysis of a geochemical anomaly, in, Bartsch-Winkler, Susan, and Reed,

K.M., eds., The U.S. Geological Survey in Alaska--Accomplishments during 1983: U.S. Geological Survey Circular 945, p. 82-83.

Plafker, George, 1987, Regional geology and petroleum potential of the northern Gulf of Alaska continental margin, in, Scholl, D.W., Grantz, A., and Vedder, J.G., eds., Geology and Resource Potential of the Continental Margin of Western North America and Adjacent Ocean Basins: American Association of Petroleum Geologists Circum-Pacific Council, Earth Sciences Series, no. 6, p. 229-268.

Roe, C.H., 1994, U.S. Bureau of Mines mineral investigations in the Unakwik area, Chugach National Forest, Alaska: U.S. Bureau of Mines Open-file Report OF 5094, $194 \mathrm{p}$.

Schrader, F. C., 1900, A reconnaissance of a part of Prince William Sound and the Copper River district, Alaska, in 1898: U.S. Geological Survey 20th Anniversary Report, pt. 7, p. 341-423. 
Sherman, G.E., 1987, Estimates of remaining lode gold endowment in selected mining districts of Alaska: U.S. Bureau of Mines Information Circular, IC 9133, 26 p.

Sherman, G.E., and Jansons, Uldis, 1984, Feasibility of gold and copper mining in the Chugach National Forest, Alaska: U.S. Bureau of Mines Open-file Report, OF 125-84, $49 \mathrm{p}$.

Singer, D.A., 1986, Descriptive model of Cyprus massive sulfides, in , Cox, D.P., and Singer, D.A., eds., Mineral Deposit Models: U.S. Geological Survey Bulletin 1693, p. 131-133.

Swainbank, R.C., Clautice, K.H., and Nauman, J.L., 1997, Alaska's mineral industry-1997: Alaska Department of Natural Resources, Division of Geological and Geophysical Surveys, Special Report 52, 65 p.

Tuck, Ralph, 1933, The Moose Pass-Hope district, Kenai Peninsula, Alaska: U.S. Geological Survey Bulletin 849-I, p. 469-530.

Tysdal, R.G., and Case, J.E., 1982, Metalliferous mineral resource potential of the Seward and Blying Sound quadrangles, southern Alaska: U.S. Geological Survey Miscellaneous Field Studies Map MF-880H, scale 1:250,000.

Wahrhaftig, Clyde, 1965, Physiographic divisions of Alaska: U.S. Geological Survey Professional Paper 482, $52 \mathrm{p}$.

Winkler, G. R., Miller, R. J., MacKevett, E. M., Jr., and Holloway, C. D., 1981, Map and summary table describing mineral deposits in the Valdez quadrangle, southern Alaska: U.S. Geological Survey Open-file Report 80-892-B, scale 1:250,000, 2 sheets.

Wojcik, J.R., 1984, Geologic features described for large global gold placer deposits: Mining Engineer, v. 36, no. 11, p. 1528-1530.

Yeend, W.E., 1986, Descriptive model of placer Au-PGE, in , Cox, D.P., and Singer, D.A., eds., Mineral Deposit Models: U.S. Geological Survey Bulletin 1693, p. 261. 
Table 1. Summary of mineral assessments within the Chugach National Forest area.

\begin{tabular}{|c|c|c|c|}
\hline Area & Scale & Reference & Comments \\
\hline \multicolumn{4}{|c|}{ Regional Assessment } \\
\hline South-central Alaska & $1: 1,000,000$ & $\begin{array}{l}\text { MacKevett and } \\
\text { Holloway (1977) }\end{array}$ & $\begin{array}{l}\text { Shows areas favorable for different } \\
\text { mineral deposit types. Lists known } \\
\text { deposits }\end{array}$ \\
\hline \multicolumn{4}{|c|}{ AMRAP Studies (Alaska Mineral Resource Assessment Program) } \\
\hline $\begin{array}{l}\text { Seward and northern } \\
\text { Blying Sound quadrangles }\end{array}$ & $1: 250,000$ & $\begin{array}{l}\text { Tysdal and Case } \\
\text { (1982) }\end{array}$ & $\begin{array}{l}\text { Gives probabilistic estimate for } \\
\text { undiscovered Cyprus-type massive } \\
\text { sulfide deposits }\end{array}$ \\
\hline Valdez quadrangle & $1: 250,000$ & $\begin{array}{l}\text { Winkler and others } \\
\text { (1981) }\end{array}$ & $\begin{array}{l}\text { Shows location of mines, prospects, and } \\
\text { mineral occurrences }\end{array}$ \\
\hline $\begin{array}{l}\text { Cordova and northern } \\
\text { Middleton Island } \\
\text { quadrangles }\end{array}$ & $1: 250,000$ & $\begin{array}{l}\text { Goldfarb and } \\
\text { others (1992) }\end{array}$ & $\begin{array}{l}\text { Areas ranked based on their potential for } \\
\text { containing undiscovered resources }\end{array}$ \\
\hline Anchorage quadrangle & $1: 250,000$ & $\begin{array}{l}\text { Madden-McGuire } \\
\text { and Winkler } \\
\text { (1994) }\end{array}$ & $\begin{array}{l}\text { Areas ranked based on their potential for } \\
\text { containing undiscovered resources }\end{array}$ \\
\hline
\end{tabular}

Assessments Covering the Chugach National Forest (CNF)

\begin{tabular}{|c|c|c|c|}
\hline $\mathrm{CNF}$ & $1: 250,000$ & $\begin{array}{l}\text { Nelson and others } \\
\text { (1984) }\end{array}$ & $\begin{array}{l}\text { Ranks areas of mineral potential on their } \\
\text { likelihood for future mineral activity. } \\
\text { Forms basis for this report }\end{array}$ \\
\hline $\mathrm{CNF}$ & $1: 250,000$ & $\begin{array}{l}\text { Jansons and others } \\
\text { (1984) }\end{array}$ & $\begin{array}{l}\text { Map and accompanying table depict } \\
\text { known mines, prospects, and mineral } \\
\text { occurrences }\end{array}$ \\
\hline $\mathrm{CNF}$ & $1: 250,000$ & Bliss (1989) & $\begin{array}{l}\text { Probabilistic assessment of undiscovered } \\
\text { mineral deposits }\end{array}$ \\
\hline $\begin{array}{l}\text { Small area north of } \\
\text { Glacier Island in northern } \\
\text { Prince William Sound }\end{array}$ & $1: 63,360$ & $\begin{array}{l}\text { Nelson and others } \\
\text { (1994) }\end{array}$ & $\begin{array}{l}\text { Probabilistic estimate of a } 1,000 \mathrm{~km}^{2} \\
\text { area; report also addresses Forest Service } \\
\text { "minerals area management" concerns }\end{array}$ \\
\hline Same as above & $1: 63,360$ & Roe (1994) & $\begin{array}{l}\text { Evaluation of known mines, prospects } \\
\text { and mineral occurrences in a } 1,000 \mathrm{~km}^{2} \\
\text { area; includes a mining feasibility } \\
\text { determination }\end{array}$ \\
\hline
\end{tabular}


Table 2. Estimates of undiscovered resource endowment for the entire Chugach National Forest at the 50th percentile by deposit type (from Bliss, 1989). Values for $\mathrm{Au}$ and $\mathrm{Ag}$ in thousand of grams; $\mathrm{Cu}, \mathrm{Pb}$, and $\mathrm{Zn}$ in thousand metric tons.

\begin{tabular}{lcr}
\hline Deposit type & Commodit & 50th percentile value \\
\hline Chugach gold & $\mathbf{y}$ & \\
& $\mathrm{Au}$ & 2,000 \\
Placer gold & $\mathrm{Ag}$ & 340 \\
Cyprus-type massive & $\mathrm{Au}$ & 600 \\
sulfide & $\mathrm{Cu}$ & 360 \\
& $\mathrm{~Pb}$ & 0 \\
& $\mathrm{Zn}$ & 59 \\
& $\mathrm{Au}$ & 6,600 \\
Polymetallic vein & $\mathrm{Ag}$ & 140 \\
& $\mathrm{Au}$ & 36 \\
& $\mathrm{Ag}$ & 47,000 \\
& $\mathrm{Cu}$ & 12 \\
& $\mathrm{~Pb}$ & 6,700 \\
& $\mathrm{Zn}$ & 2,200
\end{tabular}


Table 3. Listing, for comparative purposes, of the mineral resource tract numbers used by Nelson and others (1984) and geographic names used in this report for the same (or modified) mineral resource tracts. Abbreviations of the geographic names, given in parentheses, are used in the text and on Figure 2.

\begin{tabular}{|c|c|}
\hline Tract number ${ }^{1}$ & Geographic Name \\
\hline 1 (modified) & Girdwood (G) \\
\hline 2 (modified) & Resurrection Creek (RC) \\
\hline 3 & Kenai Lake (KL) \\
\hline 4 & Resurrection Peninsula (RP) \\
\hline 5 (modified) & Harriman Fjord (HF) \\
\hline 6 (modified) & Blackstone Glacier (BG) \\
\hline & Sargent Icefield (SI) \\
\hline 7 & Puget Bay (PB) \\
\hline 8 (modified) & $\begin{array}{l}\text { College Fjord-Columbia Glacier (CF- } \\
\text { CG) }\end{array}$ \\
\hline 9 & Port Wells-Columbia Glacier (PW-CG) \\
\hline 10 & Culross Island $(\mathrm{CI})$ \\
\hline $\begin{array}{l}11 \\
12\end{array}$ & Knight Island (KI) \\
\hline 13 & - \\
\hline 14 & Latouche Island (LI) \\
\hline 15 & \\
\hline 16 & Wells Bay-Long Bay (WB-LB) \\
\hline 17 & Glacier Island (GI) \\
\hline 18 & Ellamar-Port Fidalgo (E-PF) \\
\hline 19 & Copper River Addition (CRA) \\
\hline 20 & \\
\hline 21 & $\begin{array}{l}\text { Hinchinbrook Is-Hawkins Island- } \\
\text { Cordova. (HI-HI-C) }\end{array}$ \\
\hline 22 & McKinley Peak (MP) \\
\hline & Miles Glacier (MG) \\
\hline 23 (modified) & Mt Hamilton (MH) \\
\hline 24 (modified) & Don Miller Hills (DMH) \\
\hline 25 (modified) & Kayak Island (KA) \\
\hline
\end{tabular}




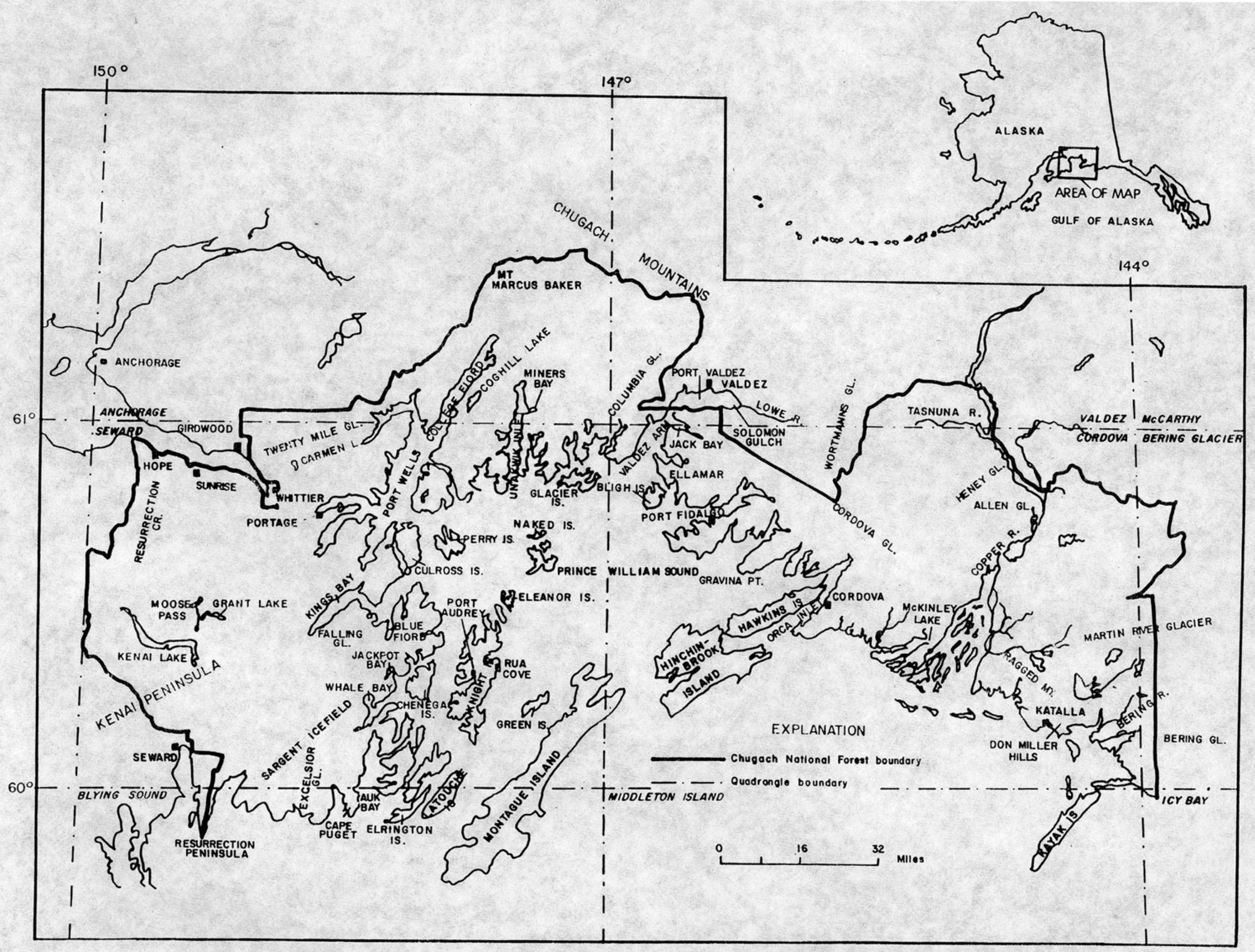

Figure 1.--Location and geographic setting of the Chugach National Forest, Alaska. 


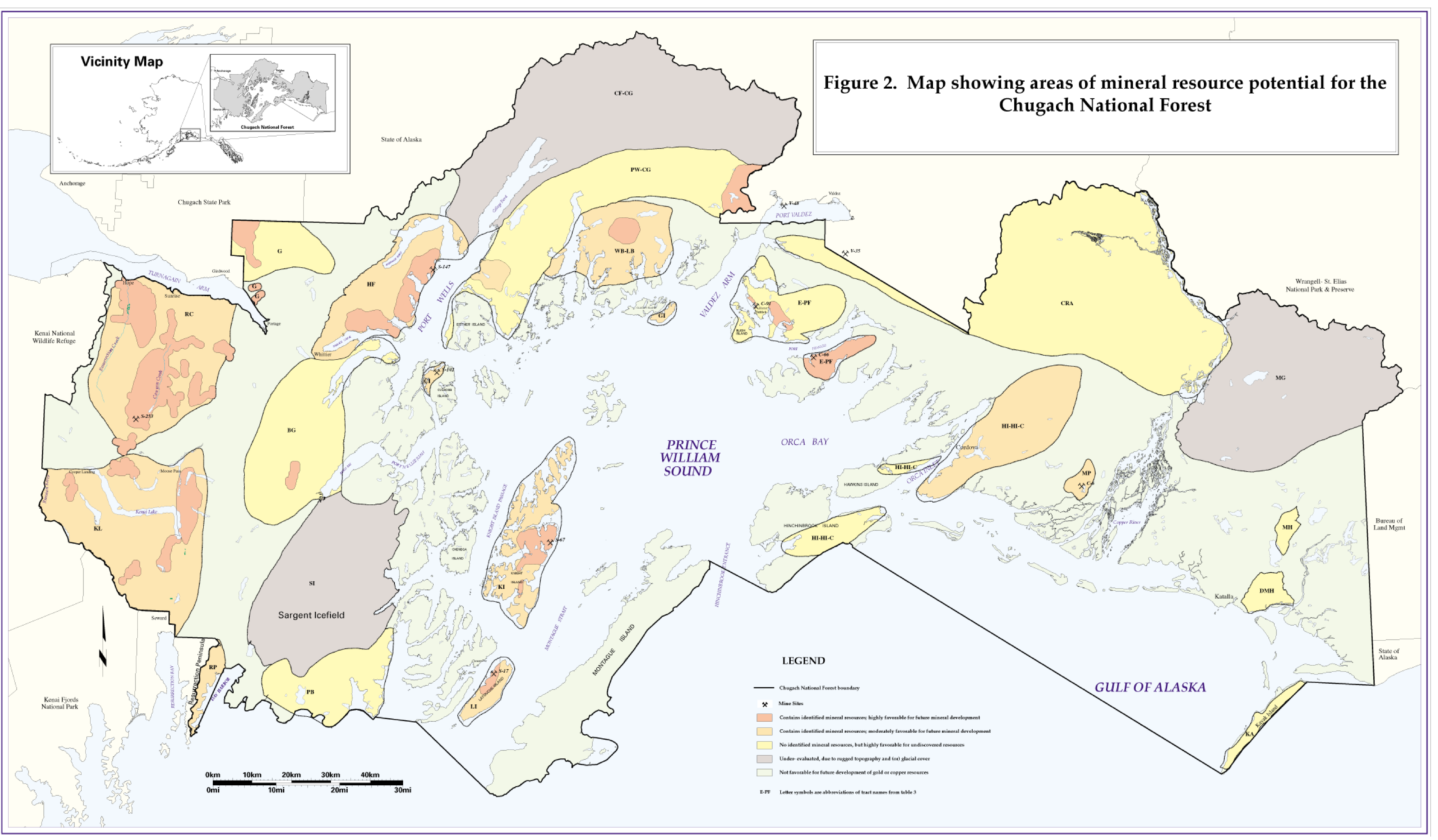


Figure 2. Map showing areas of mineral resource potential for the Chugach National Forest. Letter symbols are abbreviations of tract names from Table 3. Red areas contain identified resources and are considered most favorable for development and production. Orange areas contain identified resources and are considered moderately favorable for development and production. Yellow areas are considered highly favorable for containing undiscovered mineral resources. Gray areas are considered under-evaluated with respect to their mineral potential due to rugged topography and glacial cover. Uncolored areas lack geologic criteria indicating potential for resources, contain resources not addressed in this report, or contain deposits having a low probability of future development activity. 